UVEITIS AND DERMAL DEPIGMENTATION (VOGT-KOYANAGI-HARADA-LIKE SYNDROME) IN AKITA DOGS. I. CLINICAL ASPECTS

PAULO SERGIO DE MORAES BARROS Associate Professor

Faculdade de Medicina Veterinária e Zootecnia da USP

ANGELICA MENDONÇA VAZ SAFATLE

BVM

Faculdade de Medicina Veterinária e Zootecnia da USP

TELMA APARECIDA MALERBA

BVM

Faculdade de Medicina Veterinária e Zootecnia da USP

KENJI YRIO

BVM

JOSE ALVARENGA

Professor

Faculdade de Medicina Veterinária e Zootecnia da USP

MARIA HELENA MATIKO AKAO LARSSON

Associate Professor

Faculdade de Medicina Veterinária e Zootecnia da USP

BARROS, P.S.M.; SAFATLE, A.M.V.; MALERBA, T.A.; YRIO, K.; ALVARENGA, J.; LARSSON, M.H.M.A. Uveitis and dermal depigmentation (Vogt-Koyanagi-Harada-like syndrome) in Akita dogs. I. Clinical aspects. Braz J. vet. Res. anim. Sci., São Paulo, v.28, n.1, p.75-9, 1991.

SUMMARY: The Vogt-Koyanagi-Harada syndrome have been studied in human beings. A similar syndrome was first reported in Japan in Akita dogs. Several reports have appeared in veterinary literature in Canada, in the United States and in United Kingdom affecting different breeds. We described the clinical aspects of the Vogt-Koyanagi-Harada-like syndrome in twenty-one Akita dogs. The ocular findings include bilateral anterior or posterior uveitis or a severe panuveitis, cutaneous depigmentation around eyelids, lips, nasal planum, and scrotum which can present ulceration and crusting. The cause of the disease remains unknown and the administration of high doses of corticosteroids is the treatment of choice. This is the first communication of the syndrome in Brazil.
UNTTERMS: Liveitis, depigmentation; Vogt-Koyanagi-Harada Syndrome; Dogs

\title{
INTRODUCTION
}

The association between ocular and dermal lesions have been studied in human beings. The Vogt-KoyanagiHarada syndrome is one of these alterations.

It was first described by Vogt in 1906, Koyanagi in 1914, and Harada in 1926. The disease that produces chronic anterior and posterior uveitis, vitiligo, poliosis, dysacusis, tinnitus, and meningitis has an unknown etiology.

In dogs a similar syndrome was first reported in Japan in Akita dogs by ASAKURA et al. 1, 1977. Since this, several reports have eppeared in the veterinary literature. In Canada, BUSSANICH et al. 2, 1982 described a granulomatous panuveitis and depigmentation in two Samoyeds and Irish Setter and correlated this with the syndrome described in the Japanese literature. Following these reports, the syndrome was recognized in the Australian Shepherd and siberian Husky in France (FABRIES 5,1984 ) in the United States; in an Akita dog (ROMATOWSKY 9 , 1985) in the United States; in a Golden Retrivier, Old England Sheepdog, Saint Bernard, Australian Shepherd and Siberian Husky (KERN et al. ', 1985) in the United States; in a Collie (CAMPBELl et al. ${ }^{3}, 1986$ ) in the United States. COTTRELL; BARNETT ${ }^{4}$ (1987) described the first case of the syndrome in an Akita dog in the United $k$ ingdom.

Ocular findings include bilateral anterior or posterior uveitis or a severe panuveitis. Affected dogs may present serous or bullous retinal detachment, although some dogs have no evidence of anterior uve it is.

Dermal depigmentation is a comon sign. Central nervous system involvement is very rare, only COTTRELL; BARNETT ${ }^{4}$ (1987) have described a case of Harada's disease in a female japanese Akita, with neurological signs.

In a study by ASAKURA (1983)* over a 14 year period (1967 to 1982) which involved 40 dogs (37 Akitas, 1 Ainu, 1 Shiba and 1 Kishu), a male to female distribution showed a ratio 7 to 3 . The age at diagnosis varied from 8 months to 4 years old, but dogs from 8 months to 2 years old were predominantly affected.

Biographic data from 14 dogs from the world literature shows eight males and six females, and the

* aSAKuRA, I.W. (Chiron Animal Hospital - Japan). Personal Communication, 1983. 
age of the patients ranged from 13 months to six years (mean age 2.8 years) (MORGAN ${ }^{8}, 1989$ ).

As in human beings, the cause of the disease in dogs remains unknown, although basic laboratory data, a search for infectious agent, and immunological assays were conducted (KERN et al. ${ }^{7}$ 1985).

Topical and subconjunctival corticosteroids, topical atropine, and systemic corticosteroids in immunossupressive doses are usually used (MORGAN ${ }^{8}$, 1989).

This paper describes twenty-one cases of weitis and dermal depigmentation in the Akita dog. These are the first reports of the disease in Brazil.

\section{MATERLAL AND METHOD}

Twenty-one Akita dogs, 15 males and 6 females, 7 months to 6 years old, were examined by the Ophthalmology Section of the Veterinary Hospital of the University of São Paulo. The dogs were examined by

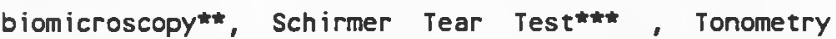

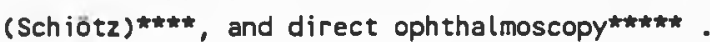

\section{RESULTS AND DISCUSSION}

In this report, the sex distribution showed a ratio of 5 males to 2 females, which is similar to that described by ASAKURA (1983)*, but different from the findings of HASEGAWA ${ }^{6}$ (1985) and MORGAN 8 (1989) who indicated that no sex predispodition existed. The age at diagnosis varied from 7 to 72 months with the following distribution: age of 12 months or less - 4 dogs; 13 months to 30 months - 13 dogs; 31 to 72 months - 4 dogs; which is similar to the age distribution described in the literature.

The symptoms referred to by the owners were: poor vision red eyes, and blepharospasm with excessive lacrimation. The clinical findings included varying deepness of corneal opacity (Fig. 1A), and conjunctival and episcleral congestion. Smooth keratic precipitates and aqueous flare could be detected in cases where the cornea was not so cloudy as to avoid the examination of the anterior segment, and early in the course of the disease. Anterior capsule pigment deposition and hyphema were seen in a few cases. Posterior synechiae in a variable extension were seen

\footnotetext{
* LF M2 D.F. Vasconcelos S.A. - Brasil

\#* Alcon Laboratories - USA

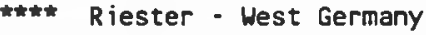

Welch Allyn - USA

* aSAKURA, I.W. (Chron Animal Hospital - Japan). Personal Communication, 1983.
}

in all cases (Fig. 1A). The iris depigmentation, a not so common sign was seen in one dog (Fig. 1B). Vitreous opacity an cataract formation were seen in most cases, and ocular fundus examination was not possible because of corneal opacity. Some dogs exhibited retinal depigmentation, papiledema and lack of blood vessels. Secondary glaucoma and lens luxation were common. In 5 patients with buphthalmia and blindiness, hyphema, descemet's fracture and profound corneal neovascularization were present.

Cutaneous depigmentation was typically present around eyelids, lips, nasal planun (Fig. 1C), and scrotum.

Only two dogs with chronic disease and not receiving treatment had ulceration and crusting of the depigmentated areas (Fig. 1D), and a lichenoid dermatitis reaction was revealed skin biopsies as reported by ScotT ${ }^{10}$ (1984).

The administration of high doses of prednisone "per os", and topical dexamethasone (ointment and eye drops) and atropine (eye drops) kept the eyes under control for variable periods of time, but dogs with secondary glaucoma did not respond satisfactorily to therapy. Cutaneous repigmentation ocurred following successful treatment. Six patients are presently under control, and their visual condition is good. When we attempted to diminish the oral corticosteroids dose below immunossupressive levels the symptoms returned. There was no follow-up on 8 dogs.

The common occurence of meningitis and dysacousia reported in human patients has not been recognized in dogs, with only COTTRELL; BARNETT ${ }^{4}$ (1987) describing a case of a young japanese Akita showing neurological abnormalities. In one of our cases, a reference to dysacousia was made by the owner, but could not be confirmed.

The search for the cause of this disease is in progress. HASEGAWA ${ }^{6}$ (1985) described $\mathrm{clinical}$ cases in Akita dogs in Japan and suggested a hereditary predisposition. COTTRELL; BARNETT ${ }^{4}$ (1987) also suggested a hereditary condition. We were not able to study this factor in our cases.

BARROS, P.S.M.; SAFATLE, A.M.V.; MALERBA, T.A.; YRIO, K.; ALVARENGA, J.; LARSSON, M.H.M.A. Uveite $e$ dermodespigmentação (Síndrome de Vogt-Koyanagiharada) en cães Akita. I. Aspectos clínicos. Braz.J. vet. Res. anim. Sci., São Paulo, v.28, n.1, P.75-9, 1991.

RESUMO: A sindrome de Vogt-Koyanagi-Harada, caracterizada pela associação de uveíte e alteraçōes cutaneas e de meninge, de causa desconhecida é bastante estudada na oftalmologia humana. Foi primeiro descrita no Japão una síndrome semelhante en cães da 
raçs Akita, sendo que relatos em outras raças e outros países como Canadá, Estados Unidos e Inglaterre foram feitos posteriormente. Descrevemos pela primeira vez no Brasil esta associação úveo-dermatológica em 21 cães da raça Akita. Caracterizada por uveite e despigmentação ao redor das pálpebras, lábjos, narina e escroto podendo haver ulceraçāo com formação de crostas nestas regiōes. A administração de altas doses de corticosteróides é o tratamento de eleição.

UNTTERMOS: Uveite, despigmentação; Sindrome de Vogt Koyanagi-Harada; Cães
09-ROMATOWSKI, J. A Uveodermatological syndrome in an Ak ita dog. J.Amer. Anim. Hosp. Ass., v.21, P.777-80, 1985 .

10-SCOTT, D.W. Lichenoid reactions in the skin of dogs: clinicopathologic correlations. J. Amer. Anim. Hosp. Ass., v.20, P.305-17, 1984.

Recebido para publicaçāo em 09/10/90 Aprovado para publicaçāo em 19/02/91

\section{REFERENCES}

01-ASAKURA, S.; TAKAHASHI, K.; ONISHI, T. VogtKoyanagi-Harada syndrome (Uveites diffusa acuta) in the dog. Jap. vet Med., V.673, P.445-55, 1977.

02-BUSSANICH, M.N.; ROOTMAN, J.; DOLMAN, C.L. Granulomatous pan uveitis and dermal depigmentation in dogs. J. Amer. Anim. Hosp. Ass., v. 18, p.131-8, 1982.

03-CAMPBELL, K.L.; MCLAUGHLIN, S.A.; REYNOLdS, H.A. Generalized leukoderma and poliosis following uveitis in a dog. J.Amer. Anim. Hosp. Ass., v.22, p. 121-4, 1986.

04-COTTRELL, B.D.; BARNETT, K.C. Harada's disease in the Japanese Akita. J. small Anim. Pract., v.28, p.517-21, 1987 .

05-FABRIES, L. Syndrome "VKH" chez le chien. Au sujet de deux cas cliniques. Prat. méd.-chir. Anim. comp., v.19, $0.393-7,1984$.

06-HASEGAWA, A. Mucocutaneous ocular syndrome in Akita dogs. Anim. Eye Res., v.4, P.17-21, 1985.

07-KERN, T.J.; WALTON, D.K.; RIIS, R.C.; MANNING, T.O.; LARATTA, L.J.; DZIEZYC, J. Uveitis associated with poliosis and vitiligo in six dogs. J.Amer. Vet Med. Ass., v.187, P.408-14, 1985.

08-MORGAN, R. Vogt-Koyanagi-Harada syndrome in humans and dogs. Compend. Contin. Educ., v.11, p.1211-8, 1989. 

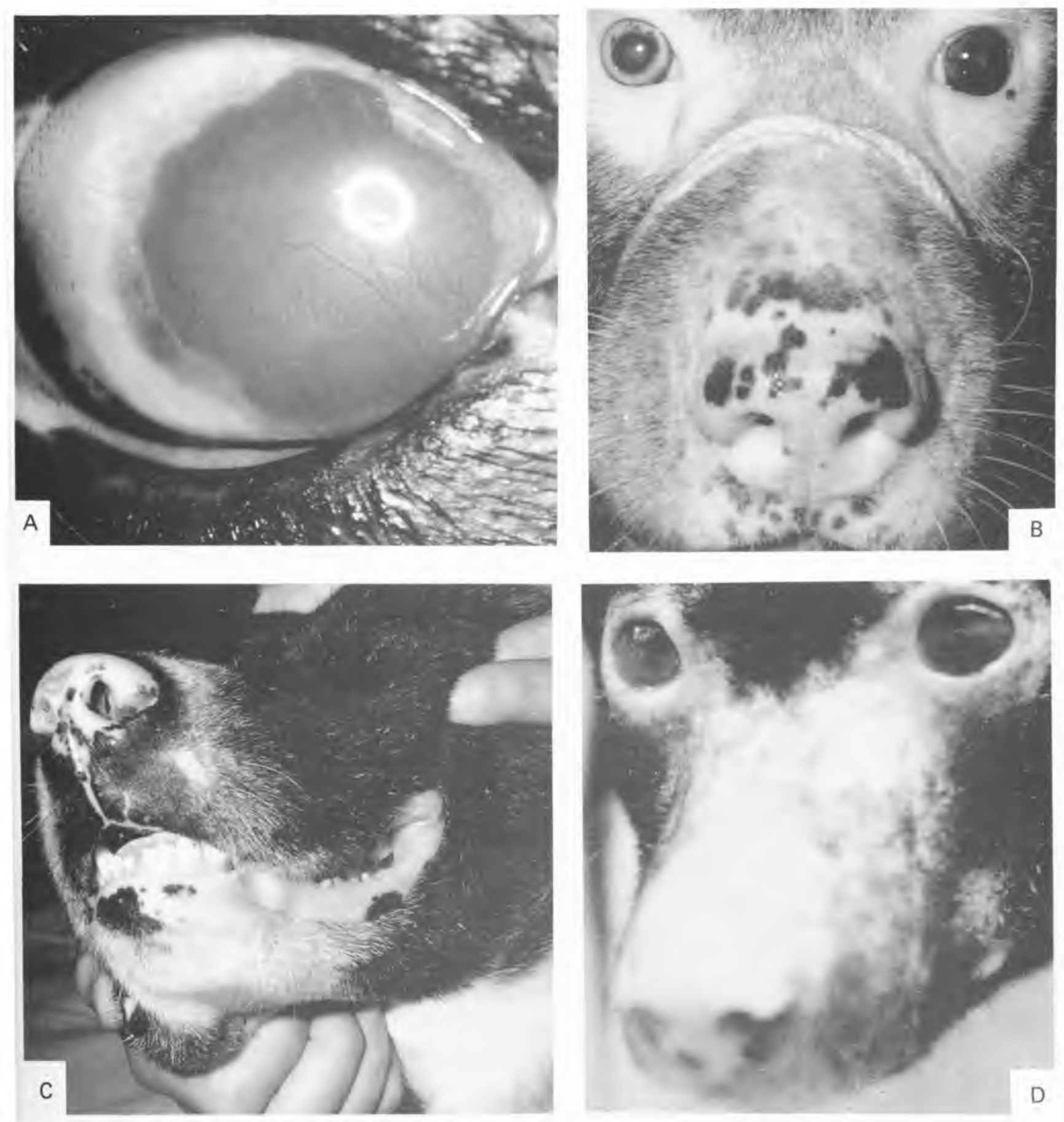

FIGURE 1- A) Left eye with lid depigmentation including $3^{\text {rd }}$ eyelid margin; profound vascularization and opacity of cornea: iris edema and several posterior synechiae.

B) Right iris depigmentation and poliosis.

C) Depigmentation of lips and nasal planum.

D) Ulceration and crusting in nasal region and around eyelids. 